\title{
Termination of Employment-Based on Efficiency in Indonesian Company
}

\author{
Kadek Agus Sudiarawan ${ }^{1}$, Putu Edgar Tanaya ${ }^{2}$, \\ Kasandra Dyah Hapsari ${ }^{3}$
}

${ }^{1}$ Faculty of Law.Universitas Udayana, Indonesia, E-mail: agus_sudiarawan@unud.ac.id

${ }^{2}$ Faculty of Law.Universitas Udayana, Indonesia, E-mail: edgar_tanaya@unud.ac.id

${ }^{3}$ RAH (The House of Legal Experts), Indonesia, E-mail: kasandradyah@gmail.com

Submitted: October 2, 2020; Reviewed: October 21, 2020; Accepted: October 27, 2020

\begin{tabular}{|c|c|}
\hline Article Info & Abstract \\
\hline $\begin{array}{l}\text { Keywords: } \\
\text { Industrial Relations Disputes, } \\
\text { Termination of Employment (Laid } \\
\text { off), Company Efficiency. } \\
\text { DOI: } \\
\text { 10.25041/fiatjustisia.v15no1.2015 }\end{array}$ & $\begin{array}{l}\text { The different interest between employer and } \\
\text { employee is potentially causing Industrial Dispute } \\
\text { between them. Industrial Disputes is dominated by } \\
\text { Termination of Employment (laid off) dispute; one of } \\
\text { the reasons is company efficiency. Based on that } \\
\text { matter, it needs to be studied regarding its legality, } \\
\text { procedure, employees' rights and the pattern of } \\
\text { Industrial Dispute Settlement regarding laid off } \\
\text { through company efficiency. Based on these } \\
\text { problems, several conclusions can be drawn. Firstly, } \\
\text { Termination of Employment must be based on a } \\
\text { valid reason under the law. Secondly, Termination } \\
\text { of Employment due to company's efficiency can only } \\
\text { be done on the condition that the company } \\
\text { permanently closed. Thirdly, in the case of } \\
\text { termination of employment for company efficiency, } \\
\text { the company must pay attention to the employee's } \\
\text { rights in the form of compensation based on } \\
\text { consideration of wages and the employee s duration } \\
\text { of work. Fourthly, the pattern of Industrial Dispute } \\
\text { Resolution that can be adopted by the parties is } \\
\text { bipartite, tripartite and Industrial Relation Court. }\end{array}$ \\
\hline
\end{tabular}

\section{A. Introduction}

The industry is a sector that has a strategic position and plays a vital role in realizing economic development in Indonesia. The Industrial Sector creates productive sectors both in goods and services in Indonesia. One of the crucial roles of the industry is an employment agency in Indonesia which based on 
data from Indonesian Statistics Agency in 2019 the open unemployment rate is 5,28 per cent, or 5 of 100 labour has not been absorbed by the labour market. ${ }^{1}$ This becomes an important data for the government to follow up on, bearing in mind that the state has the responsibility for meeting basic social and economic needs through providing decent work and live hoods for all Indonesians. Article 27 paragraph (2) of the Indonesia Republic's 1945 Constitution stated a person's right to work and the ups and downs of a company's business and the national economy had become a dilemmatic problem faced by the government, companies and employees. ${ }^{2}$ On 20 April 2020, the Indonesian Ministry of Manpower issued data that the number of employees affected by layoffs and remuneration is 2,084,593 employees from the formal and informal sectors from 116,370 companies. Formal employees who were laid off are 241,431 employees from 41,236 companies. ${ }^{3}$ Industrial activities in Indonesia then develop industrial relations. Starting from the relationship between employers and employee, only profit-oriented companies without considering the business ethics and norms will make the company management tend to be of the view that a value is deemed to be acceptable if it benefits the company and vice versa. ${ }^{4}$ To ensure certainty in the fulfilment of the obligations and rights of the corporates and the employees in industrial relations, Law Number 13 of 2003 concerning Manpower is enacted. Then Law Number 2 of 2004 concerning Settlement of Industrial Relations regulated the dispute settlement. Internally, the company also produces an autonomous legal product in the form of a working contract, company regulations, including collective labour agreement between the company and the labour union.

Industrial relations between employers and employees are often not working in harmony because of the differences interest between the two parties. Employers have an interest in the smooth running of their business while the employee has an interest in getting a job to earn income. When there is a conflict of interest between the two parties, the industrial relation dispute potentially occurs. The emergence of industrial relation disputes cause by disagreement between the employers and the employees, disputes due to disagreement is later become the object of industrial relations disputes. ${ }^{5}$

\footnotetext{
${ }^{1}$ https://www.bps.go.id/website/materi_ind/materiBrsInd-20191105114507.pdf, Accessed on 1 June 2020.

${ }^{2}$ Budi Santoso, "Justifikasi Efisiensi sebagai Alasan Pemutusan Hubungan Kerja," Mimbar Hukum 25, no. 3 (2013): 402-415, 403, DOI: 10.22146/jmh.16080.

3 https://www.kemnaker.go.id/news/detail/menaker-badai-pasti-berlalu-panggil-kembalipekerja-yang-ter-phk-nanti, Accessed on 10 June 2020.

${ }^{4}$ Mochammad Rizki Aziz, I. G. A. A. Noviekayati, "Dukungan Sosial, Efikasi Diri Dan Resiliensi Pada Karyawan Yang Terkena Pemutusan Hubungan Kerja, "Persona: Jurnal Psikologi Indonesia 5, no. 1 (2016): 62-70, 62, DOI:10.30996/persona.v5i01.742.

${ }^{5}$ Muhammad Saleh, Lilik Mulyadi, Seraut Wajah Pengadilan Hubungan industrial Indonesia (Bandung: Citra Aditya Bakti, 2012), 11.
} 
Article 2 Industrial Relations Settlement regulates that the forms of industrial relations disputes consist of disputes over rights, disputes over interest, termination of employment relation (laid off), and disputes between labour unions. From the four forms of industrial relations disputes, Termination of Employment (laid off) disputes is the most common disputes in Indonesia. Laid off disputes occur because they are conducted without the agreement of both parties or are conducted unilaterally by the employer.

Efficiency is one of the reasons why employers terminate employment both in order to reduce company losses and to adjust to changes in the company's business strategy. The reason for efficiency is stipulated in Article 164 paragraph (3) of the Manpower Law which provides an opportunity to be laid off based on efficiency is if the company closes not because it has suffered two years loss in a row or not because of forced conditions. This arrangement then caused debate among the employees, especially the union. Therefore, based on the background above, it is interesting to study in-depth about the efficiency as a basis for layoff, especially related to layoff procedures, the rights of the employees that been laid off and the patterns of resolution of disputes that occur. This research is normative legal research using a statutory approach.

\section{B. Discussion}

\section{Termination of Employment-based on Efficiency Reasons}

Industrial relations involving employers and employees are not always smooth. With the background of different interest between them, no matter how harmonious a frame of industrial relations is industrial relation disputes are difficult to avoid. Disputes are challenging to avoid because until now, the positions of employees and employers are not equal and tend to be subordinate (one over the other). ${ }^{6}$ For the employees, the issue of Termination of Employment is complex, because it linked to economic and psychological problems. Economic problems due to lay off will cause loss of income, whereas psychological problems are related to loss of their status. ${ }^{7}$

Laid off are one of the reasons for industrial relation disputes between the companies and the employees. One of the reasons for a company to terminate the employment is for the efficiency of the company. The

6 Kadek Agus Sudiarawan, Nyoman Satyayudha Dananjaya, "Konsep Penyelesaian Perselisihan Hubungan Industrial Berbasis Pemberdayaan Sebagai Upaya Peningkatan Perlindungan Hukum Terhadap Buruh Dalam Mencari Keadilan, "ADHAPER: Jurnal Hukum Acara Perdata 3, no. 1 (2018): 17-37, 17, DOI:10.36913/jhaper.v3i1.42.

${ }^{7}$ Ayu RatnaHari Putri, Solechan Sonhaji, "Perlindungan Hukum terhadap Hak-hak Pekerja yang Terkena Pemutusan Hubungan Kerja Akibat Efisiensi Perusahaan Berdasarkan Undangundang Nomor 13 Tahun 2003 Tentang Ketenagakerjaan di Kota Semarang (Studi Putusan MA Nomor 474/k/pdt. sus-phi/2013),"Diponegoro Law Journal 5, no. 2 (2016): 1-21, 2. 
Manpower Law allows employers to terminate employment because the company is making an efficiency. This is regulated in Article 164 paragraph (3) of the Manpower Law that stated:

"Employers may terminate the employment to the employees because the company closed not because they have suffered losses for two years in a row or not because force majeure but the company does efficiency, if this happens, that the employees shall be entitled to severance pay twice the amount of the severance pay stipulated in the provisions of Article 156 paragraph (2), the reward for a period of employment amounting to one time the amount stipulated in provisions of Article 156 paragraph (3) and the compensation fee by the provisions of Article 156 paragraph (4)".

Initially, the provisions of Article 164 paragraph (3) can be used by employers in terminate the employment based on company efficiency both because of consideration of reducing losses and changes in the company's business strategy. However, based on the judicial review of Article 164 paragraph (3) of the Manpower Law conducted by the Constitutional Court (as stipulated in the Constitutional Court Decision number 19/PUU-IX/2011) stated that the provisions of Article 164 paragraph (3) contradict the 1945 Constitution of The Republic of Indonesia as long as the phrase company closed does not interpret company closed permanently or company closed temporarily". Finally, the Constitutional Court of the Republic of Indonesia issued the following decision:

a. Declare Article 164 paragraph (3) of Law Number 13 of 2003 concerning Manpower (State Gazette of the Republic of Indonesia Number 39 of 2003, Supplement to the State Gazette of the Republic of Indonesia Number 4279) contrary to the 1945 Constitution of the Republic of Indonesia as long as the phrase "company is closed" does not mean company permanently closed or closed temporarily":

b. Stating Article 164 paragraph (3) of Law Number 13 of 2003 concerning Manpower (State Gazette of the Republic of Indonesia of 2003 Number 39, a supplement to the State Gazette of the Republic Indonesia Number 4279) on the phrase "closed company" has no binding legal force as long as it does not mean "company permanently closed or company closed temporarily";

From the provisions above, Article 164 paragraph (3) of the Manpower Law is declared unconstitutional. It has no legal force as long as the phrase "closed company" does not mean that the company is permanently closed or the company is not temporarily close. The meaning of the provisions is that efficiency can only be done if the company is permanently closed. The Constitutional Court of the Republic of Indonesia emphasized that if the company temporarily closes Article 164 paragraph (3) of the Manpower Act is considered unconstitutional and cannot be fully enforced. Therefore, the calculation of the rights received by the employees when they laid off for the 
reasons of efficiency (severance pay, reward money for their work period, compensation fee) must refer to The Constitutional Court of the Republic of Indonesia Decision No. 19/PUU-IX/2011 which can only be applied if the company is permanently closed. After the Constitutional Court of the Republic of Indonesia Decision, the company must use Article 164 paragraph (3) carefully as the basis for terminating the employment, where the company must refer to the Constitutional Court of the Republic of Indonesia Decision and the company must be permanently closed.

Based on the provisions of Article 57 of Law Number 24 of 2003 concerning Constitutional Court stated "Decision of the Constitutional Court whose ruling states that the material contained in paragraphs, articles and or parts of the law is contrary to the Indonesia Republic's 1945 Constitution, the material contained in paragraphs, articles and/or parts of the law have no legal force. From this provision, the status of the Constitutional Court's decision is considered equivalent to the law, because the Constitutional Court Decision stating that an article has no binding legal force must be published within 30 working days at the latest since the decision is pronounced.

As for the consideration of the Constitutional Court Decision as regulated in Letter Number SE-907/MEN/PHI-PPHI/X/2004 concerning Prevention of Mass Termination of Employment in conjunction with Letter Number SE643/MEN/PHI-PPHI/IX/2005 concerning the Prevention of Termination of Employment stated that laid off are the last option as an effort to improve company efficiency after previously made other efforts in the framework of such efficiency. Based on this, it is regulated that companies cannot lie off before taking the following efforts:

a. Reduce wages and top-level employee facilities, for example, manager and director levels;

b. Reduce shift;

c. Limit/eliminate overtime work;

d. Reduce working hours;

e. Reduce work days;

f. Temporarily applying unpaid leave for the employees in rotation;

g. Not extending the contract for the employees whose contracts have expired;

h. Provide pensions for those who already meet the requirements.

In consideration of its decision, the Constitutional Court view that employees must be seen as one of the assets of the company, therefore that efficiency alone without the closedown of the company cannot be used as an excuse to lie off. This follows the concept of pareto efficiency that in the application of efficiency to seek profits must not harm others (benefit someone and injures no one) or at least if it cannot make others better at least do not 
make others worse (no person can be made better off without making someone else worse off). ${ }^{8}$

Besides, this research was carried out concurrently with legislation process of work creation bill which caused various pros and cons in the society, specifically from the employment side in responding to the various regulatory changes related to Industrial Relations in the human resources cluster of the related law.

The Job Creation Bill, specifically in human resources cluster, is generally directed at strengthening the protection of the employment and increasing the role and the welfare of the employees in supporting the investment ecosystem. This regulation amends removes or sets new regulations for several provisions regulated, one of which is the Employment Law related to Termination of Employment, especially Termination of Employment-based on efficiency. In the provisions of the Job Creation Bill, between Article 154 and Article 155, 1 (one) Article is inserted, namely Article 154A. In the provisions of Article 154A, it regulates 14 reasons for Termination of Employment, where point b regulates that companies make efficiency. It is also regulated that in addition to the reasons for Termination of Employment as referred to in paragraph (1), other reasons for Termination of Employment can be stipulated in the employment contract as referred to in Article 61 paragraph (1), and further provisions regarding procedures for Termination of Employment are regulated in a Government Regulation.

\section{Termination of Employment of All the Employees for the closing of one Business Unit in the company}

The provisions of Article 164 paragraph (3) of the Manpower Act that regulates laid off due to company efficiency cannot be applied to the terminate the employment plan that will be carried out for all employees in one business unit contained in a company. This is based on the provisions of Article 164 paragraph (3) of the Manpower Act "Employers may terminate the employment to the employees because the company closed not because they have suffered losses for two years in a row or not because force majeure but the company does efficiency, if this happens, that the employees shall be entitled to severance pay twice the amount of the severance pay stipulated in the provisions of Article 156 paragraph (2), the reward for a period of employment amounting to one time the amount stipulated in provisions of Article 156 paragraph (3) and the compensation fee in accordance with the provisions of Article 156 paragraph (4)."

\footnotetext{
${ }^{8}$ Fajar Sugianto, Syofyan Hadi, "Efisiensi Dan Daya Saing Free Flow of Skilled Labour Dalam Perspektif Economic Analysis of Law: Telaah Peraturan Presiden Nomor 20 Tahun 2018," Jurnal Rechts Vinding: Media Pembinaan Hukum Nasional 7, no. 3 (2018): 393-408, 394.
} 
Judicial review of Article 164 paragraph (3) of the Manpower Act conducted by the Constitutional Court outlined in the Constitutional Court Decision No. 19/PUU-IX/2011 then states that the provisions of Article 164 paragraph (3) contradict the 1945 Constitution of The Republic of Indonesia as long as the phrase company closed does not mean company closed temporarily. Based on the regulation above, it can be analyzed that the phrase closed company must be interpreted as permanent closing. Therefore, if a business unit in a company is closed either temporarily or replaced by another business unit or permanently closed, it cannot be used as a basis for implementing the termination based on efficiency. The reasons are, it is explicitly mentioned in the Manpower Act and the Constitutional Court Decision there is a key phrase that is "company closed" (permanently). Therefore, the provisions cannot be applied to closed business units. This is based on the understanding of the difference between company and business units. The company, as regulated in Chapter I General Provisions Article 1 point 6 of the Manpower Law is defined as:

a. Any form of business, which employs employees by paying wages or other forms of compensation;

b. Social business and other businesses that have management and employ others by paying wages or other forms of compensation.

Meanwhile, the definition of the company in the provisions of Article 1 of Law No. 8 of 1997 concerning company documents is consist of the following elements:

a. every form of business

b. permanently and continuously activity

c. profit-oriented

d. by individuals or business entities

e. established and domiciled in the territory of the Indonesia Republic

\section{Employees Rights to Termination of Employment for Efficiency Reasons}

Laid off cases in the company legal protection for the employees must be given. The termination of employment may give rise to the rights and obligations of each party if the termination procedure is legally recognized or legally valid. ${ }^{9}$ Laid off in the context of industrial relation can occur both from the initiative of the employers and directly from the employees. The basis for laid off under the provisions of the Manpower Act can arise from a variety reason.

Starting from the resignation well on their own accord, when the contract ends, employees entering retirement age, employees make serious mistakes,

${ }^{9}$ Sri Zulhartati, "Pengaruh Pemutusan Hubungan Kerja Terhadap Karyawan Perusahaan," Jurnal Pendidikan Sosiologi dan Humaniora 1, no. 1 (2010). 
the authorities hold employees, the company suffer losses, employees are absent continuously, employees die, employees do violation of contract, company regulation or collective labour agreement, change of status, merger, consolidation of change of the company ownership, up to termination of employment due to efficiency reasons.

For the laid-off that arise from company initiatives, before terminating the employment the company must explain the reasons for terminating the employment and compensation received by the employees following the regulation and autonomous law that apply to the companies. For employers, laid-off create an obligation to provide compensation for the employees, the more employees that will be terminate the higher work period of the employees, the higher the compensation costs that must be prepared by the companies. ${ }^{10}$ The amount of compensation in the event of termination of employment is regulated differently in the Manpower Act based on the reasons underlying the termination of employment. The provisions of Article 156 paragraph (1) of the Manpower Law stipulates that in the event of termination of employment, the employer is required to pay severance payment and reward for a period of employment and compensation fee which should be received by the employees. The provisions of Article 156 paragraph (2), (3) and (4) of the Manpower Law then specifically regulates the calculation formula for compensation received by the employees including calculation of severance payment, the reward for period employment, and compensation fee which is calculated based on the number of wages and working period of the employees.

\section{Settlement of Industrial Relations Dispute Regarding Termination of Employment for Efficiency Reasons}

Laid off disputes in the context of industrial relation is the most dominating issue in Industrial Relations Disputes. Work relations established between employers and employees are based on the agreement. Therefore, an agreement between the parties becomes the main thing in terminating work relations. Laid off disputes based on Article 1 point 4 of the Settlement of Industrial Disputes Law are defined as disputes arising from differences in opinion between the parties relating to work termination.

The mechanism for resolving Industrial Relations Disputes is not only guided by Law Number 2 of 2004 concerning Settlement of Industrial Relation, but there are several other parts regulated in Law Number 13 of 2003 concerning Manpower and autonomous Law which applies to the companies

\footnotetext{
${ }^{10}$ Ari Hernawan, "Keberadaan Uang Pesangon Dalam Pemutusan Hubungan Kerja Demi Hukum di Perusahaan yang Sudah Menyelenggarakan Program Jaminan Pensiun, "Jurnal Kertha Patrika Fakultas Hukum Universitas Udayana 3, no. 8 (2016): 1-17, 1, DOI: 10.24843/KP.2016.v38.i01.p01.
} 
either in the form of employment contract, company regulation or contain in collective labour agreement made by the management with the union. The Manpower Law and autonomous Law in each company are a source of material law. In contrast, the Settlement of Industrial Relation Law acts as a ceremonial law in Indonesian Manpower system.

When a dispute occurs, the provisions of Article 2 of the Settlement of Industrial Relations Law divided the form of Industrial Dispute Resolution into four types namely: Disputes of Right, Disputes of Interest, Termination of Employment (laid off) Disputes and Disputes between the union in one company. The Settlement of Industrial Relations Law accommodates a threetier dispute resolution system through bipartite, followed by tripartite and lastly through the Industrial Relations Court.

In the event of a dispute (disagreement) between the employees and the employer related to the implementation of laid off, the main procedure that must be taken by both parties is to conduct negotiations/bipartite. Settlement of disputes through bipartite is identical to the peace forum. ${ }^{11}$ If the negotiation is successful, it will be contained directly in the collective agreement which is the central pillar used to settle Industrial Relations Disputes because the collective agreement is essentially a consensus which is undoubtedly a winwin solution for the parties. ${ }^{12}$ The collective agreement is binding and must be implemented by both parties. ${ }^{13}$

If the negotiation failed, both parties could ask for assistance from the human resources officers for mediation or conciliation. Finally, if the process failed, the dispute resolution can be continued to the court. The period for the settlement of industrial disputes as stipulated in the regulation includes a full 30 days for bipartite implementation, a tripartite process (mediation, conciliation or arbitration) for 30 days, a maximum of 50 days at the Industrial Relations Court and for the termination of employment disputes and disputes of rights an appeal can be made by the Supreme Court to be terminated no later than 30 working days from the date of receipt of the appeal.

\section{Conclusion}

Based on the above matters, here are some conclusions obtained:

1. That in carrying out a Termination of Employment, the company must be guided by the grounds/reasons for valid laid off as stipulated in the

\footnotetext{
${ }^{11}$ Pengaribuan, Juanda, Seluk Beluk Hukum Acara Pengadilan Hubungan Industrial (Jakarta: MISI, 2016), 82.

${ }^{12}$ Kadek Agus Sudiarawan, et al. "Position of Collective Labor Agreement as a Company Autonomous Law: Industrial Relation Dispute Settlement Approach," Jurnal Magister Hukum Udayana (Udayana Master Law Journal) 8, no. 4 (2019): 457-470, 457, DOI:10.24843/JMHU.2019.v08.i04.p02.

${ }^{13}$ Indi Nuroini, "Penerapan Perjanjian Bersama dalam Pemutusan Hubungan Kerja," Jurnal Yudisial 8, no. 3 (2015): 319-338, 320, DOI:10.29123/jy.v8i3.61.
} 
provisions of the applicable laws and regulations. Industrial relations dispute settlement agency can only carry out the termination of employment by an entrepreneur if the interests of the parties are not in line so that there is no agreement. Termination of Employment due to efficiency must refer to the statutory that will be better if it can be avoided or they can choose another alternative policy that can protect both the employment and the employer, such as the steps that are regulated in Ministry of Manpower Circular Letter Number SE-907/MEN/PHI-PPHI/X/2004 concerning the Prevention of Termination of Employment in conjunction with Circular Letter Number SE-643/MEN/PHI-PPHI/IX/2005 concerning the Prevention of Termination of Employment that stated laid off is the last option as an effort to improve company efficiency after previously other effort is made in the framework of such efficiency.

2. In contrast, the provisions of Article 164 paragraph (3) of the Manpower Law are legal provisions governing Termination of Employment-based on company efficiency reason. This provision is based on the Constitutional Court Decision Number 19/PUU-IX/2011 then declared contrary to the Republic of Indonesia's 1945 Constitution and has no binding legal force insofar as the phrase "closed company" in Article 164 paragraph (3) of the Manpower Act is not interpreted as "the company close temporarily" this means that Termination of Employment for the reasons of company efficiency can only be done if the company permanently closed.

3. For Termination of Employment, the company must also provide compensation by the employees' rights as stipulated in the Manpower Act following the reasons for the Termination of Employment. Also, in calculating the amount of the compensation is based on wages and work tenure of each employee as stipulated in the provisions of Article 156 of the Manpower Act and or regulated explicitly in the Autonomous Law (company regulation/collective labour agreement) that applies to the company.

4. The main procedure that must be adopted by both parties in the event of a dispute between employees and employers related to the implementation of laid-off is by negotiating/bipartite. If it is successful, it will be contained directly in the collective agreement. If it is failed, the employees or the employers can ask assistance from the human resources officers (mediation or conciliation). Finally, if the process failed, the dispute resolution can be continued through the Industrial Relations Court with the filing of a lawsuit over the Termination of Employment (laid off).

\section{References}

1945 Constitution of the Republic of Indonesia. 
Aziz, Mochammad Rizki, Noviekayati, I. G. A. A. "Dukungan sosial, efikasi diri dan resiliensi pada karyawan yang terkena pemutusan hubungan kerja." Persona: Jurnal Psikologi Indonesia 5, no. 1, 2016: 62-70, DOI:10.30996/persona.v5i01.742.

Constitutional Court Decision Number 19/PUU-IX/2011.

Hari Putri, Ayu Ratna., Son haji, Solechan. "Perlindungan Hukum terhadap Hak-hak Pekerja yang Terkena Pemutusan Hubungan Kerja Akibat Efisiensi Perusahaan Berdasarkan Undang-undang Nomor 13 Tahun 2003 Tentang Ketenagakerjaan di Kota Semarang (Studi Putusan MA Nomor 474/k/pdt. sus-phi/2013)." Diponegoro Law Journal 5, no. 2, 2016: $1-12$.

Hernawan, Ari. "Keberadaan Uang Pesangon Dalam Pemutusan Hubungan Kerja Demi Hukum di Perusahaan yang Sudah Menyelenggarakan Program Jaminan Pensiun." Jurnal Kertha Patrika Fakultas Hukum Universitas Udayana 3, no. 8, 2016: 1-17, 1, DOI:10.24843/KP.2016.v38.i01.p01.

https://www.bps.go.id/website/materi_ind/materiBrsInd-

20191105114507.pdf, Accessed on 1 June 2020.

https://www.kemnaker.go.id/news/detail/menaker-badai-pasti-berlalu-

panggil-kembali-pekerja-yang-ter-phk-nanti, Accessed on 10 June 2020.

Job Creation Bill.

Law Number 13 of 2003 concerning Manpower.

Law Number 2 of 2004 concerning Settlement of Industrial Relations;

Letter Number SE-907/MEN/PHI-PPHI/X/2004 concerning prevention of Mass Termination of Employment in conjunction with Letter Number SE-643/MEN/PHI-PPHI/IX/2005 concerning the Prevention of Termination of Employment.

Nuroini, Indi. "Penerapan Perjanjian Bersama dalam Pemutusan Hubungan

Kerja." Jurnal Yudisial 8, no. 3, 2015: 319-338, DOI: 10.29123/jy.v8i3.61.

Pengaribuan, Juanda, Seluk Beluk Hukum Acara Pengadilan Hubungan Industrial. Jakarta: MISI, 2016.

Saleh, Muhammad and Lilik Mulyadi, Seraut Wajah Pengadilan Hubungan Industrial Indonesia. Bandung: Citra Aditya Bakti, 2012.

Santoso, Budi. "Justifikasi Efisiensi sebagai Alasan Pemutusan Hubungan Kerja." Mimbar Hukum-Fakultas Hukum Universitas Gadjah Mada 25, no. 3, 2013: 402-415, DOI: 10.22146/jmh.16080.

Sudiarawan, Kadek Agus, and Nyoman Satyayudha Dananjaya. "Konsep Penyelesaian Perselisihan Hubungan Industrial Berbasis Pemberdayaan Sebagai Upaya Peningkatan Perlindungan Hukum Terhadap Buruh Dalam Mencari Keadilan." ADHAPER: Jurnal Hukum Acara Perdata 3, no. 1, 2018: 17-37, DOI: 10.36913/jhaper.v3i1.42. 
Sudiarawan, Kadek Agus, et al. "Position of Collective Labor Agreement as a Company Autonomous Law: Industrial Relation Dispute Settlement Approach." Jurnal Magister Hukum Udayana (Udayana Master Law Journal) 8, no. 4, 2019: 457-470, 457, DOI: 10.24843/JMHU.2019.v08.i04.p02.

Sugianto, Fajar., Hadi, Syofyan. "Efisiensi Dan DayaSaing Free Flow Of Skilled Labour Dalam Perspektif Economic Analysis Of Law: Telaah Peraturan Presiden Nomor 20 Tahun 2018." Jurnal Rechts Vinding: Media Pembinaan Hukum Nasional 7, no. 3, 2018: 393-408.

Zulhartati, Sri. "Pengaruh Pemutusan Hubungan Kerja Terhadap Karyawan Perusahaan." Jurnal Pendidikan Sosiologi dan Humaniora 1, no. 1 2010 . 